\title{
WF, Rat Strain
}

National Cancer Institute

\section{Source}

National Cancer Institute. WF, Rat Strain. NCI Thesaurus. Code C14390.

A Wistar substrain derived by Furth (1945), this inbred rat strain is a white albino with pink eyes, genotype c. The Wistar Furth rat carries a heteropyenotic $Y$ chromosome that is used as a cellular marker. Leukemia develops in $15-22 \%$ of these rats, which is characterized by mononuclear cells with reddish granules. The Wistar Furth rat exhibits good reproductive performance and is docile, with an averages life span of 22 months. 